ROCZNIK PRZEMYSKI t. 57

LITERATURA I JEZYK z. 2 (25) 2021

MALGORZATA SZCZEPANIK (Kraków)

ORCID: 0000-0003-4268-9662

\title{
METODA BADAŃ KOMPARATYSTYCZNYCH W RECEPCJI STAROPOLSKICH UTWORÓW LITERACKICH. DYSKURS O KOMPETENCJACH BADACZA W UJĘCIU KRYTYCZNEJ ANALIZY DYSKURSU
}

\begin{abstract}
The Method of COMParative ReSearch in the Reception of Old Polish LITERARY WORKS. A DISCOURSE ON RESEARCHERS' COMPETENCES FROM THE PERSPECTIVE of Critical Discourse Analysis
\end{abstract}

The paper discusses the use of the comparative research method to carry out explication of Old Polish literary works. The article has two main research aims: the first one focuses on theoretical aspects of discourse and the Critical Discourse Analysis, which is at the same time a tool to carry out the second aim, i.e. performing discursive activities concerned with the competences of a researcher using the comparative method while interpreting Old Polish literature. The paper consists of two planes. The first one is the completion of theoretical assumption, covering historical overview of the major moments in comparative literature and literary theory. The second plane is specification of the Critical Discourse Analysis in order to detail aspects referring to the comparatist's research competences.

Keywords: Critical Discourse Analysis, discourse, comparative literature, literary theory, researcher's competences, Old Polish literature

Słowa kluczowe: Krytyczna Analiza Dyskursu, dyskurs, komparatystyka, teoria literatury, kompetencje badacza, literatura staropolska

Metoda badań komparatystycznych, pomimo upływu wielu lat od powstania, nieustannie święci triumfy w rozprawach literaturoznawczych. Teza ta została oparta na analizie powstałych w ciągu dwóch ostatnich dekad publikacji dotyczących badań tekstów kultury w ujęciu interdyscyplinarnym. Niniejszy artykuł ma dwa cele: rozważania teoretyczne wokół dyskursu oraz Krytycznej Analizy Dyskursu jako narzędzia jego eksplikacji, a także założenia praktyczne - wykorzystanie prezentowanego narzędzia w celu przeprowadzenia dyskursu wokół kompetencji badacza, dokonującego działań komparatystycznych podczas badania staropolskich utworów literackich. 
Rozkwit teorii literatury miał miejsce w wieku XX. Wówczas po raz pierwszy poddano krytyce idee dotyczące odbioru dzieła literackiego. Powstałe w tym okresie prace dostarczyły nowych metod oraz spojrzeń na kategorie należące do płaszczyzn teoretycznoliterackich. Starano się na nowo zdefiniować terminy uznawane niegdyś za podstawowe. W efekcie zmianie uległa koncepcja dotycząca przyjmowanego przez literaturoznawców ,zdrowego rozsądku” ${ }^{1}$ w odbiorze tekstów kultury. Interpretacja wniosków wykazała, iż przywołane pojęcie jest sztucznym konstruktem, przez dekady wdrażanym przez badaczy w formie cząstki elementarnej, której istnienia nie można podważyć. Implikacją dokonanych działań stała się redefinicja zagadnień dotyczących między innymi recepcji, analizy i interpretacji oraz sensów danego tekstu kultury, a także osadzenia dzieła w kontekście kulturowym - zjawiskach towarzyszących jego powstawaniu, literacko-kulturowemu „ja” i całokształtowi twórczości autora.

Istotą tego zwrócenia się ku przeszłości jest ukazanie wagi krytycznych refleksji teoretycznoliterackich także dla przyszłości literatury. W XXI w. krytyczna analiza powinna być kontynuowana oraz poszerzać dyskurs o kompetencjach badacza. Dwie najistotniejsze definicje teorii literatury - niezbędne dla dalszych eksplikacji tematyki tegoż wywodu - to ujęcia Josepha Natolia oraz Ralpha Cohena. Pierwszy z badaczy sformułował myśl, iż teoria jest „dyskursem interpretującym inne dyskursy, to znaczy krytyką kulturową"2, natomiast drugi orzekł, że jest ona „dyskursem o dyskursach"

Spektrum badań w obrębie samego dyskursu stanowi szeroki obszar normalizacji, rozciągając się na wiele dziedzin naukowych. Teun van Dijk ${ }^{4}$ zagadnienie ujmuje na trzech płaszczyznach, dzieląc je na dyscypliny: ,a) które skupiają się na «samym» dyskursie, czyli na strukturach tekstu lub wypowiedzi; b) które badają dyskurs i komunikację pod kątem ich uwarunkowań poznawczych; c) które poświęcają szczególną uwagę kulturze oraz strukturom społecznym. To właśnie ów trójkąt: dyskurs-poznanie-społeczeństwo wyznacza w gruncie rzeczy obszar interdyscyplinarnych badań nad dyskursem"s.

Kamilla Biskupska skategoryzowane przez Teuna van Dijka aspekty klasyfikuje następująco: „1. Dyskurs jako zjawisko językowe [...]. 2. Dyskurs jako zdarzenie komunikacyjne [...]. 3. Dyskurs jako zdarzenie kulturowe"6. Pierwszy punkt

${ }^{1}$ J. Culler, Teoria literatury, tłum. M. Bassaj, Warszawa 2002, s. 13.

${ }^{2}$ Cyt. za: A. Burzyńska, M.P. Markowski, Teorie literatury XX wieku. Podręcznik, Kraków 2006, s. 13.

${ }^{3}$ Cyt. za: ibidem, s. 14.

${ }^{4}$ Zob. T.A. van Dijk, Badania nad dyskursem, [w:] Dyskurs jako struktura i proces. Praca zbiorowa, red. T.A. Dijk, thum. G. Grochowski, Warszawa 2001, s. 9; D. Howarth, Dyskurs, tłum. A. Gąsior-Niemiec, Warszawa 2008; Język, dyskurs, społeczeństwo. Zwrot lingwistyczny w filozofii społecznej, red. L. Rasiński, Warszawa 2009.

${ }^{5} \mathrm{~K}$. Biskupska, Analiza dyskursu i krytyczna analiza dyskursu, [w:] Wspótczesne teorie społeczne w kręgu ujęć paradygmatycznych, red. M.S. Szczepański, A. Śliz, Opole 2014, s. 369.

${ }^{6}$ Ibidem, s. 370. 
obejmuje lingwistyczny charakter języka, skupiając się na organizacji znaków, gramatyce, słownictwie, stylu, czyli wszystkich cząstkach jego systemu i struktury. Badacze przyjmujący tę formę analizy zajmują się elementami dotyczącymi właściwości formalnych języka, nie podejmując działań analitycznych skierowanych na jego społeczne wymiary. Drugi aspekt charakteryzuje się szeroko rozumianą komunikacją - zarówno ustną, jak i pisemną, obejmującą , wyrażenie” konkretnego zagadnienia. Ujęcie to zawiera także właściwości dotyczące gatunków ${ }^{7}$, typów oraz wariantów mowy. Trzeci aspekt koncentruje się na kulturowych wyróżnikach dyskursu i bada ponadjęzykowe, ,choć za pomocą systemu językowego realizowane” zjawiska w danym społeczeństwie. Kultura - w tymże obszarze - stanowi rezerwuar akumulujący elementy semiotyczne, definiowanie pojęć, odbiór, „odczuwanie” uniwersum, ale też systematyzuje naukę, mądrość, konkretyzuje „,sposoby, granice i kryteria poznania"9. Tworzy obraz - wykładnię danego kręgu kulturowego. Niniejsza płaszczyzna opisu dyskursu, odrzucając lingwistyczne cechy pojęcia, stanowi odwrotność pierwszego (językoznawczego) aspektu klasyfikacji. Podkreśla się zarazem, że analiza oraz interpretacja zjawisk w obrębie dyskursu kulturowego determinowane są „kompetencją i doświadczeniem badacza” ${ }^{10}$.

Dyskurs jest nieodzownym pierwiastkiem w spektrum ,społecznej konstrukcji życia społecznego [...]. Ma siłę sprawczą, lecz to, czy siła ta jest aktualizowana, zależy od warunków społecznych - [...] jednoczesnych wpływów innych sił sprawczych" " . Zatem obszar dyskursu, w którym dochodzi do polemiki, powinien być wyznaczony, aczkolwiek nie może ograniczać refleksji badającego. Analiza poddanych rozważaniom idei musi być wolna od narzuconych aksjomatów, które jednoznacznie wyznaczają poglądy wpływające na ostateczny wynik przeprowadzanych zabiegów. Rezultat dokonanego w danym aspekcie procesu (dyskursu) winien być wytworem „czystym”, na którego wynik ma wpływ jedynie kompetencja badacza, będąca jednocześnie brzemieniem odpowiedzialności, którą ten na siebie przyjmuje.

${ }^{7}$ Zob. M. Bachtin, Problem gatunków mowy, [w:] idem, Estetyka twórczości słownej, thum. D. Ulicka, wstęp E. Czaplejewicz, Warszawa 1986, s. 349; C. Goddard, A. Wierzbicka, Język, kultura i znaczenie - semantyka międzykulturowa, [w:] Kognitywne podstawy języka i językoznawstwa, red. E. Tabakowska, Kraków 2001, s. 175-202; F. de Saussure, Miejsce języka wśród faktów mowy, [w:] idem, Kurs językoznawstwa ogólnego, tłum. K. Kasprzyk, przedm. W. Doroszewski, Warszawa 1991, s. 38-43; A. Wierzbicka, Akty mowy, [w:] Semiotyka i struktura tekstu. Studia poświęcone VII Międzynarodowemu Kongresowi Slawistów, Warszawa 1973. Praca zbiorowa, red. M.R. Mayenowa, Wrocław 1973, s. 201-221; eadem, Genry mowy, [w:] Tekst i zdanie. Zbiór studiów, red. T. Dobrzyńska, E. Janus, Wrocław 1983, s. 125-129; eadem, Różne kultury - różne języki - różne akty mowy, [w:] eadem, Język-umyst - kultura, wybór pod red. J. Bartmińskiego, Warszawa 1999, s. 56-73.

${ }^{8}$ K. Biskupska, op. cit., s. 370.

${ }^{9}$ A. Grzymała-Kazłowska, Socjologicznie zorientowana analiza dyskursu na tle współczesnych badań nad dyskursem, „Kultura i Społeczeństwo” 2004, t. 48, nr 1, s. 15.

${ }^{10}$ K. Biskupska, op. cit., s. 371.

${ }^{11}$ A. Duszak, N. Fairclough, Wstęp. Krytyczna analiza dyskursu - nowy obszar badawczy dla lingwistyki i nauk społecznych, [w:] Krytyczna analiza dyskursu. Interdyscyplinarne podejście do komunikacji społecznej, red. A. Duszak, N. Fairclough, Kraków 2008, s. 16. 
Inną znaczącą kwestią wokół rozważań nad dyskursem jest próba nadania definicji oraz wydzielenia rozumienia pomiędzy podmiotem refleksji a „tekstem”. Pojęcia „dyskurs” i „tekst” w przestrzeni kulturowej występują równolegle, wzajemnie się uzupełniając. Zazwyczaj powiązanie bywa silne, gdyż terminy te uzewnętrzniają się w zjawisku, w którym nawzajem się wyrażają. Owa „wyrażalność” manifestuje się także w konstruowanych definicjach. Przykładem takiego zastosowania jest cytowana za Ruth Wodak formuła: „,dyskurs jest to złożona wiązka współwystępujących i następujących po sobie aktów językowych, które przejawiają się na jednym lub kilku obszarach życia społecznego, jako powiązane tematyką okazy semiotyczne, niejednokrotnie jako teksty należące do konkretnych typów semiotycznych, czyli gatunków mowy ${ }^{12}$. [...] to systemy otwarte i niejednorodne. Stale powstają nowe podtematy, a wzajemne nawiązania pomiędzy tekstami i dyskursami stwarzają nowe obszary działania społecznego" "13. Biorąc pod uwagę, iż „tekst” to „materialnie trwały wytwór działań językowych”"14, stanowi on spektrum aktywności oraz implikacji danych dyskursów. Zatem aby idea danego dyskursu przetrwała próbę czasu, konieczne jest jej zmaterializowanie w postaci tekstu. Dyskurs zaś wymaga tekstów, aby z ich pomocą można było dokonać krytycznej analizy wybranego zagadnienia.

W przestrzeni badań nad złożoną problematyką dyskursu wyszczególnić należy Krytyczną Analizę Dyskursu. To na jej obszarze odbywa się „szczegółowa analiza tekstu”"15 - warto zaznaczyć, iż „termin «tekst» używany jest tutaj w najszerszym znaczeniu, obejmuje interakcje mówione, «multimodalne» teksty telewizji i Internetu (mieszanie «trybów» języka i obrazu), a także teksty pisane i publikowane"16. Definicja Krytycznej Analizy Dyskursu cechuje się obszernością oraz rozgałęzieniem spowijającym rozliczne stanowiska krytyczne względem zależności i korelacji pomiędzy ,językiem czy dyskursem a innymi elementami («momentami») procesów społecznych"17. Niepozytywistyczne nauki ugruntowały twierdzenie, iż „zjawiska społeczne są społecznie konstruowane, a zatem stanowią domenę znaczenia - ale i związków przyczynowo-skutkowych; domenę interpretacji - ale i objaśnienia; kultury - ale i materialności; subiektywizmu - ale

\footnotetext{
${ }^{12}$ Norman Fairclough „gatunek mowy” definiuje jako „skonwencjonalizowany, w rozmaitym stopniu uschematyzowany sposób używania języka, ściśle powiązany z pewnym typem działania, jako «społecznie usankcjonowany sposób użycia języka powiązany z konkretnym rodzajem społecznego działania», cyt. za: R. Wodak, Dyskurs populistyczny. Retoryka wykluczenia a gatunki języka pisanego, tłum. J. Wawrzyniak, A. Wójcicki, [w:] Wstęp. Krytyczna analiza dyskursu ..., op. cit., s. 190.

${ }^{13}$, ,[... [ «obszar działania społecznego» może być rozumiany jako konkretny wycinek rzeczywistości społecznej, który stanowi odniesienie dla danego dyskursu. Zróżnicowaniu na poszczególne obszary działania społecznego odpowiada zróżnicowanie funkcji i społecznej instytucjonalizacji celów działań dyskursywnych", cyt. za: ibidem.

${ }^{14}$ Ibidem.

${ }^{15}$ A. Duszak, N. Fairclough, Wstęp. Krytyczna analiza dyskursu ..., op. cit., s. 18.

${ }^{16}$ Ibidem.

${ }^{17}$ Ibidem, s. 8.
} 
i obiektywizmu; działania - ale i struktury"18. Jednocześnie wieloaspektowa perspektywa prowadzonych prób oraz rekonesans rozważań uwidoczniły, iż „powstawanie, konsolidacja, reprodukcja i transformacja wszelkich zjawisk społecznych wymaga dialektycznej relacji między «znaczeniem» (a więc kulturą, interpretacją, subiektywizmem i działaniem) a «materialnością»"19.

Krytyczna Analiza Dyskursu obejmuje wyniki szczegółowych obserwacji oraz obserwacji procesów zachodzących w poddanym badaniu społeczeństwie, na podstawie których naukowcy formułują znaczenia, sensy i perspektywy semiotyczne. Dyscyplina ta jest narzędziem w rękach analizujących - niczym klucz stanowi ,semiotyczny «punkt wejścia» w procesy społeczne, które są wewnętrznie ukonstytuowane, jako dialektyczne relacje między rozmaitymi elementami i momentami społecznymi, obejmującymi dyskurs i elementy niedyskursywne" ${ }^{\prime 20}$. Przedstawiony obraz szeregu zachodzących interakcji zarazem nadaje Krytycznej Analizie Dyskursu wymiar interdyscyplinarny.

Dwie dekady temu przedstawiciele licznych ośrodków naukowych w Polsce rozpoczęli interdyscyplinarny dyskurs obejmujący kompetencje badacza wykorzystującego metodę badań komparatystycznych w analizie tekstów kultury staropolskiej. Drugim celem niniejszego studium jest próba ponownego pochylenia się nad najistotniejszymi problemami towarzyszącymi recepcji dzieł powstałych przed połową XVIII w. W celu odświeżenia refleksji omawiane tutaj zagadnienia są rozpatrywane zgodnie z nakreśloną powyżej ideą Krytycznej Analizy Dyskursu.

Zgłębiając metodę badań komparatystycznych, w celu podkreślenia wagi poruszonej kwestii warto stworzyć zarys historycznego obrazu zaistniałych na jej gruncie problemów badawczych, których początek przypada na wiek XVIII. Wówczas Immanuel Kant w swoich pracach zaproponował zmianę modelu recepcji umysłu ludzkiego. Wywarła ona znaczący wpływ na postrzeganie człowieka, a ściślej ujmując - pracy jego mózgu. Filozof odżegnywał się od przyjmowanego przez wielu naukowców realizmu głoszącego, iż umysł stanowi jedynie mechanizm przeznaczony do realizacji indyferentnej adnotacji rozlicznych symboli, wartości i wydarzeń, a jego działanie charakteryzuje się tym, że „w podobny sposób odtwarza on związki przyczynowe zachodzące w czasie i przestrzeni" ${ }^{21}$. Oświeceniowy myśliciel sformułował nowatorskie założenie, iż umysł, charakteryzując się wysokim potencjałem poznawczym oraz swoistą aktywnością, jest predysponowany do wieloaspektowej analizy oraz interpretacji przedmiotu badań i przyjmuje między innymi zasadę wzajemnych porównań.

Współczesny Kantowi Johann Gottfried Herder w swych pracach naukowych dotyczących działań komparatystycznych, spektrum aktywności badawczej

\footnotetext{
${ }^{18}$ Ibidem, s. 18.

${ }^{19}$ Ibidem, s. 8.

${ }^{20}$ Ibidem, s. 15.

${ }^{21}$ E. Kasperski, Kategorie komparatystyki, Warszawa 2010, s. 16.
} 
skupił na kategorii literatury narodowej oraz problemach metodologicznych, które przez lata wytworzyły się na jej gruncie. Dokonując deskrypcji, wyróżnił niebagatelne znaczenie uwarunkowań oraz determinant, które odcisnęły znamiona w procesie powstawania danego dzieła. Podejmując studia nad powyższymi czynnikami, Herder jednocześnie wyeksponował wpływ kompetencji badającego tekst na wyniki przeprowadzonych działań, czyli recepcję utworu. Komparatysta nieposiadający wiedzy obejmującej historię, obyczaje, kulturę, język oraz ideały danego narodu lub społeczności nie dokona rzetelnej analizy w tychże zakresach, a jej status będzie narażony na zdezawuowanie. Aspektem wiążącym się z powyższymi wyróżnikami jest wskazanie niemożności eksplikacji utworu „obcego" za pomocą „doświadczeń” własnej nacji (abstrahując od badań, których celem nadrzędnym jest takież porównanie). Filozof w swym dorobku twórczym wykazał, iż istnieje zbiór kontekstów, które w ciągu wieków zostały wytworzone przez rozliczne narody. To wśród nich pojawia się cząstka mająca charakter ponadindywidualny, określana jako „duchowe współuczestnictwo"22 w kreacji internacjonalnego, wielopłaszczyznowego dobra. Fakt wykorzystania jej interpretacyjnych właściwości uzależniony jest od świadomości badacza o jej istnieniu. Zarysowana tu koncepcja Herdera wywarła zasadniczy wpływ na konstruowanie dalszych teorii dotyczących filozofii, idei oraz historii, a także kultury i narodu.

Twórcy licznych systematyzacji, obejmujących tworzenie oraz kształtowanie rdzeni nauki porównawczej, dokonali krytycznego oglądu aksjomatów będących konsekwencją analizy immanentnej, która została wytworzona przez idę̨ holistyczną. Zespół powstałych segmentów ukazał celowość oraz uzasadnienie zintensyfikowania deliberacji, obejmującej rolę i kompetencje badacza tekstów kultury, których wydźwięk akumuluje się w wyniku przeprowadzanych przez niego analiz. Wielość myśli wokół tychże rozważań przyczyniła się do otwarcia dzieła na rozliczne zabiegi komparatystyczne, dzięki czemu zaczęło ono zyskiwać szereg nowych interpretacji.

Komparatystyka - zwłaszcza przeprowadzana jeszcze w dobie staropolskiej swą popularność zawdzięczała teoriom poznania wywodzącym się z klasycyzmu. Wielość dokonywanych $\mathrm{w}$ owych wiekach zestawień wiązała się z przekonaniem, iż „porównanie jest istotnym elementem procesu rozumowania w ogóle, nie tylko w dziedzinie literatury. Jest ono drugim, kolejnym po analizie, ogniwem myślenia" ${ }^{23}$. To w działaniach komparatystycznych tkwiła kwintesencja wielopłaszczyznowego odczytu dzieła oraz otaczającego go świata. Konkludując: wartość szeroko rozumianego „ogniwa myślenia” danego badacza uwidoczniała się w procesie oraz wyniku przeprowadzanych porównań. Rozliczność procesów

\footnotetext{
${ }^{22}$ Ibidem, s. 16-18.

${ }^{23}$ Na podstawie wypowiedzi J. Ziętarskiej podczas konferencji w Radziejowicach zorganizowanej przez Wydział Polonistyki UW. Zapis można odnaleźć w: Badania porównawcze. Dyskusja o metodzie. Radziejowice, 6-8 lutego 1997 r., red. A. Nowicka-Jeżowa, Izabelin 1998, s. 16.
} 
komparatystycznych przyczyniała się zarazem do szlifowania ujęcia krytycznego oraz umiejętności wartościowania tekstów kultury.

Obecnie znaczenie oraz powszechna wiedza na płaszczyźnie teorii literatury, dotycząca nawet najmniejszej cząstki z kategorii komparatystyki ${ }^{24}$, jest aspektem niepodważalnym i wszechobecnym w procesie interpretacyjnym. Istnieją jednak kwestie problematyczne. Część z nich skutkuje powrotem do przytaczanych powyżej dywagacji oraz ich ponownym rozpatrywaniem w świetlne najnowszych metod.

Jednymi z najistotniejszych tekstów powstałych podczas zabiegów porównawczych są te, które zawierają błędy wynikające z metaanaliz. Dywagacje obejmujące te segmenty zapisów skupiają się na dociekaniu sensów oraz zasadności ich tworzenia. Część publikacji przedstawia obraz „samowystarczalności intelektualnej (co do materii i co do motywów operacji naukowych)"25, oderwany od zasadniczych wartości teoretycznoliterackich. W powstałych „tworach” pisarskich zatracone zostały najistotniejsze pytania: „o przedmiot: «co porównujemy?», o cel: «po co porównujemy?» i o funkcjonalną wobec przedmiotu metodę: «jak i dlaczego tak właśnie porównujemy?»"26. Absurdalne samopozbawienie się rdzenia oraz cząsteczek niezbędnych, aby przeprowadzić konkretne badanie, sprowadza wówczas wszelkie działania do przypadkowości. Wynik uzyskany dzięki irracjonalnemu zestawieniu danych jest nierzetelny i pozbawiony jakości. Jednocześnie teksty z tego segmentu podważają wartość komparatystyki literackiej w świetle szeroko rozumianej nauki. Skutkuje to zarówno wewnętrznymi, jak i zewnętrznymi rozważaniami nad jej statusem jako dziedziny badawczej.

Kwestie analogiczne prezentowane są przez komparatystów na płaszczyźnie samego obiektu komparacji. Istotą kreacji oraz dookreślenia profilu recepcji dzieła

${ }^{24}$ Jedną z podstawowych systematyzacji, zważywszy na metodę oraz technikę przeprowadzanych analiz, jest propozycja Teresy Kostkiewiczowej, która komparatystykę podzieliła na: 1 . literaturę porównawczą; 2 . literaturę powszechną; 3 . literaturę uniwersalną. Normalizacja ta - oprócz wyznaczenia podtypów - ściśle określa ich spektra oddziaływań dzięki precyzyjnym definicjom: „literatura porównawcza to [...] typ badań, które zwykle uważane są za bardziej tradycyjne, tzn. komparatystyka typu «wpływologicznego» [...]. Literatura powszechna to z kolei badania, które obejmują pewne całości kulturowo-literackie, a więc działania piśmiennictwa powstałe w różnych językach, tworzone przez różne wspólnoty etniczne w różnych czasach historycznych, ale wyrastające ze wspólnego podłoża kulturowego, mające wspólne źródło [...]. I wreszcie - literatura uniwersalna albo po prostu: literatura, w takich ujęciach badawczych, które przyjmują, że badawczym zabiegom komparatystycznym mogą być poddawane wszelkie teksty literackie (czy też wszelkie teksty kultury w ujęciu interdyscyplinarnym), niezależnie od tego, na jakim gruncie kulturowym, na jakim terenie geograficznym naszego globu i w jakim czasie powstały. Celem badań porównawczych jest tu poszukiwanie wspólnoty w literaturze jako takiej, jako totalnej całości, dociekanie jej najgłębszej istoty, charakteryzującej ją zawsze i wszędzie". Na podstawie wypowiedzi T. Kostkiewiczowej podczas konferencji w Radziejowicach zorganizowanej przez Wydział Polonistyki UW. Zapis można odnaleźć w: Badania porównawcze..., op. cit., s. 13.

${ }^{25}$ A. Nowicka-Jeżowa, Komparatystyka i filologia. Uwagi o studiach porównawczych literatury epok dawnych, [w:] Polonistyka w przebudowie. Literaturoznawstwo - wiedza o języku - wiedza o kulturze - edukacja. Zjazd Polonistów, Kraków, 22-25 września 2004, red. M. Czermińska et al., t. 2, Kraków 2004, s. 348.

${ }^{26}$ Ibidem. 
jest udzielenie odpowiedzi na pytania: „kto porównuje, w imię czego porównuje i dlaczego porównuje" ${ }^{27}$. Występująca niejednokrotnie w tejże sferze radykalność poglądów porównującego jawnie ukazuje, jak arbitralność oraz dokonana $\mathrm{w}$ imię ideologii klasyfikacja przedmiotu badania determinuje kierunek analiz $i$ argumentację. Oczywistym czynnikiem jest moment wyboru fragmentu utworu obiektu centralnego, wokół którego niczym z pajęczej przędzy zostaje utkana sieć porównań. Natomiast samo istnienie w bycie tekstowym będzie potwierdzane kolażem intertekstualnych wskazań. Proces ten stanowi możliwość oraz przynależy do zakresu działań komparatystycznych, zgodnie z ideą „,wzmocnienia znaczeń dzięki umieszczeniu dzieła w układzie odniesień wykraczających poza jego genezę źródłową"28. Jednocześnie - w myśl indywidualizacji recepcji wyników przeprowadzanych badań - uwidoczniają się problemy jednostkowe. Newralgiczny zbiór stanowią tutaj cząsteczki oderwane od sensu oraz wymiarów całości, niezgodne z ogólnym założeniem figury koła hermeneutycznego. Idealną egzemplifikacją są faktory językoznawcze oraz ideologiczno-polityczne. W pierwszym barierą jest niedostateczna wiedza z zakresu translatologii oraz nierozerwalnych z nią czynników kulturowych, niezbędnych do odczytu, a także ukazania językowego obrazu świata przedstawionego i rozszyfrowania walorów kompozycyjnych oraz stylistycznych. Podłożem drugiego są natomiast - różne typologicznie - szeroko rozumiane nadużycia interpretacyjne. Temu zjawisku towarzyszą nie tylko pytania: „w jakim aspekcie recepcje danego dzieła się różnią?”, lecz także ,jaki jest powód tejże różnicy?”. W celu utrzymania wartości, jaką stanowią działania komparatystyczne, w tym segmencie pojawiają się liczne nawoływania do monolitu nauki, którego wyrazem jest między innymi rzetelność w prowadzeniu badań.

Jednym z najbardziej problematycznych zabiegów w obrębie badań komparatystycznych jest wyjście badacza poza ramy dziedziny nauki, w której się specjalizuje. Należy przypomnieć, iż na gruncie teorii literatury wyszczególnia się dwupłaszczyznowe usytuowanie kontekstów. Na pierwszej z tych płaszczyzn plasują się „kulturowe konteksty interpretacyjne dla dzieł wszystkich sztuk, jakie wchodzą w obręb pojęcia kultury"29. Na biegunie analiz tej kategorii dochodzi do centralizacji wspólnego kontekstu, natomiast celem wszystkich procedur jest ukazanie utkanych wokół niego powiązań, relacji i współzależności. Na drugiej płaszczyźnie usytuowane zostały „miejsca wspólne” ${ }^{30}$. To one stanowią unifikator umożliwiający dokonanie interdyscyplinarnego rekonesansu. Rozpościerają

${ }^{27}$ Na podstawie wypowiedzi Zofii Mitosek podczas konferencji w Radziejowicach zorganizowanej przez Wydział Polonistyki UW. Zapis można odnaleźć w: Badania porównawcze ..., op. cit., s. 23.

${ }^{28} \mathrm{Na}$ podstawie wypowiedzi Andrzeja Lama podczas konferencji w Radziejowicach zorganizowanej przez Wydział Polonistyki UW. Zapis można odnaleźć w: Badania porównawcze ..., op. cit., s. 27.

${ }^{29}$ Na podstawie wypowiedzi Teresy Kostkiewiczowej podczas konferencji w Radziejowicach zorganizowanej przez Wydział Polonistyki Uniwersytetu Warszawskiego. Zapis można odnaleźć w: Badania porównawcze..., op. cit., s. 50.

${ }^{30}$ Ibidem. 
się od najmniejszego obszaru wyobraźni człowieka przez toposy, mity, motywy, systemy morfologiczne, ikonografię, malarstwo, style architektoniczne, muzykę aż po dziedziny ścisłe, takie jak medycyna.

Fundamentem badań interdyscyplinarnych jest określenie przez naukowca korelacji między własną specjalizacją a obszarem nauki wytyczonym jako niezbędny do przeprowadzenia analiz dopełniających lub współprowadzonych. Złożoność tych zabiegów, a także problemy wynikające z natury samego zjawiska przejawiają się już w osadzeniu porównań, które ,powinny być usytuowane nie w zakresie badań przedmiotów, lecz między nimi lub ponad nimi tak, aby porównywane były wyniki badań szczegółowych, prowadzonych autonomicznie i przy zachowaniu reguł postępowania właściwych danej dyscyplinie"31. Trzeba zaznaczyć, iż z powyższego zabiegu wyłączono dzieła, które są połączeniem sztuk - przykład stanowić mogą emblematy (łączące literaturę i obraz) lub opera barokowa (kompozycja literacko-muzyczna wykorzystująca plastykę oraz taniec). Istotnym aspektem stosowania powyższej techniki jest zawężenie perspektyw porównawczych, w efekcie czego zostaje zwiększona jakość uzyskanego wyniku. Poparcie powyższych głosów stanowi wykładnia, w której przywoływany jest fakt, iż specjalista wywodzący się $\mathrm{z}$ danego obszaru nauki dzięki odpowiedniemu przygotowaniu merytorycznemu oraz metodologicznemu dokona rzetelnego rekonesansu. Wówczas wynik takiej realizacji mógłby zostać poddany dalszym uzupełnieniom, między innymi dzięki badaniom z innych dziedzin nauki. Praca ta, dzięki odpowiedniemu wykorzystaniu kompetencji oraz wiedzy badacza specjalizującego się w danej tematyce, wykluczyłaby lub zminimalizowała błędy w publikacjach. Wykorzystanie wiedzy z odrębnych dziedzin jest procesem trudnym oraz wymagającym, jednakże nie niemożliwym. Najważniejszą wytyczną jest tutaj uzyskanie rzetelności wyniku analiz dzięki niezbędnemu wykształceniu. Jednocześnie badacz, który poszerzył kwalifikacje, w myśl tej idei zostaje włączony do interesującej go dyscypliny.

Refleksje obejmujące kompetencje naukowca wykorzystującego metodę badań komparatystycznych w recepcji staropolskich utworów literackich są elementem istotnym ze względu na zachodzące w tym procesie nieprawidłowości. Dzięki zastosowaniu Krytycznej Analizy Dyskursu przedstawione kwestie zyskały nowy wymiar odczytu, zarazem potwierdzona została aktualność problemów mających początek w osiemnastowiecznej myśli filozoficznej. Zebranie rozlicznych dyskursów, a następnie poddanie ich krytycznej analizie sprzyja wniknięciu w najmniejszy segment dylematów badawczych, przyczyniając się do szczegółowej deliberacji nad schematem powtarzalności danego błędu. Precyzyjne wskazanie rozlicznych nieprawidłowości jednocześnie sprzyja wysnuciu wniosków dotyczących zasadności ustabilizowania wymogów obejmujących kompetencję

\footnotetext{
${ }^{31}$ Na podstawie wypowiedzi Aliny Nowickiej-Jeżowej podczas konferencji w Radziejowicach zorganizowanej przez Wydział Polonistyki UW. Zapis można odnaleźć w: Badania porównawcze..., op. cit., s. 51.
} 
i wiedzę badacza - przykładowym prototypem może być tutaj ścisłe wyznaczenie zakresu jego specjalizacji. Studia porównawcze nad tekstami kultury staropolskiej ${ }^{32}$ bez wątpienia należą do jednych z najtrudniejszych w obszarze nauk humanistycznych, dlatego tak istotne jest stworzenie kompleksowej metodologii, zawierającej wyróżniki uniemożliwiające przystąpienie do działań interpretacyjnych niewykwalifikowanym naukowcom. Podjęcie próby urzeczywistnienia powyższej supozycji byłoby wzmocnieniem - obecnie zdestabilizowanej - rangi metody badań komparatystycznych w obszarze nauki.

${ }^{32}$ Zob. np. A. Nowicka-Jeżowa, Jan Andrzej Morsztyn i Giambattista Marino. Dialog poetów europejskiego baroku, Warszawa 2000. 


\section{Bibliografia}

M. Bachtin, Problem gatunków mowy, [w:] idem, Estetyka twórczości stownej, tłum. D. Ulicka, wstęp E. Czaplejewicz, Warszawa 1986, s. 348-402.

Badania porównawcze. Dyskusja o metodzie. Radziejowice 6-8 lutego 1997, red. A. Nowicka-Jeżowa, Izabelin 1998.

T. Bilczewski, Komparatystyka i interpretacja. Nowoczesne badania porównawcze wobec translatologii, Kraków 2010.

K. Biskupska, Analiza dyskursu i krytyczna analiza dyskursu, [w:] Współczesne teorie społeczne w kręgu ujęć paradygmatycznych, red. M.S. Szczepański, A. Śliz, Opole 2014, s. 369-388.

P. Borek, Literatura barokowa, [w:] Literatura polska. Sztuka, muzyka, teatr, edukacja, t. 2: Barok, red. M. Szulc, Kraków 2005, s. 33-146.

P. Borek, W stużbie Klio. Studia o barokowych pisarzach minorum gentium, Kraków 2011.

A. Burzyńska, M.P. Markowski, Teorie literatury XX wieku. Podręcznik, Kraków 2006.

A. Burzyńska, Teoria czy postteoria?, „Teksty Drugie” 1993, nr 1, s. 25-35.

J. Culler, Teoria literatury, thum. M. Bassaj, Warszawa 2002.

T.A. van Dijk, Badania nad dyskursem, [w:] Dyskurs jako struktura i proces. Praca zbiorowa, red. T.A. van Dijk, tłum. G. Grochowski, Warszawa 2001, s. 9-44.

Drogi i rozdroża współczesnej komparatystyki europejskiej, red. A. Nowicka-Jeżowa, K. Wierzbicka-Trwoga, T. Wójcik, Warszawa 2012.

A. Duszak, N. Fairclough, Wstęp. Krytyczna analiza dyskursu - nowy obszar badawczy dla lingwistyki i nauk społecznych, [w:] Krytyczna analiza dyskursu. Interdyscyplinarne podejście do komunikacji spolecznej, red. A. Duszak, N. Fairclough, Kraków 2008, s. 7-29.

C. Goddard, A. Wierzbicka, Język, kultura i znaczenie - semantyka międzykulturowa, [w:] Kognitywne podstawy języka i językoznawstwa, red. E. Tabakowska, Kraków 2001, s. 173-202.

A. Grzymała-Kazłowska, Socjologicznie zorientowana analiza dyskursu na tle wspótczesnych badań nad dyskursem, „Kultura i Społeczeństwo” 2004, t. 48, nr 1, s. 13-34.

D. Howarth, Dyskurs, thum. A. Gąsior-Niemiec, Warszawa 2008.

Język, dyskurs, społeczeństwo. Zwrot lingwistyczny w filozofii społecznej, red. L. Rasiński, Warszawa 2009.

E. Kasperski, Kategorie komparatystyki, Warszawa 2010.

Kulturowa teoria literatury. Glówne pojęcia i problemy, red. M.P. Markowski, R. Nycz, Kraków 2012.

A. Nowicka-Jeżowa, Jan Andrzej Morsztyn i Giambattista Marino. Dialog poetów europejskiego baroku, Warszawa 2000.

A. Nowicka-Jeżowa, Komparatystyka i filologia. Uwagi o studiach porównawczych literatury epok dawnych, [w:] Polonistyka w przebudowie. Literaturoznawstwo - wiedza o języku wiedza o kulturze - edukacja. Zjazd Polonistów, Kraków, 22-25 września 2004, red. M. Czermińska et al., t. 2, Kraków 2004, s. 348-361.

R. Nycz, Dziedziny zainteresowań wspótczesnej teorii literatury, „Ruch Literacki” 1996, z. 1, s. 1-18.

F. de Saussure, Miejsce języka wśród faktów mowy, [w:] idem, Kurs językoznawstwa ogólnego, thum. K. Kasprzyk, przedm. W. Doroszewski, Warszawa 1991, s. 27-31.

Sporne i bezsporne problemy wspótczesnej wiedzy o literaturze. Praca zbiorowa, red. W. Bolecki, R. Nycz, Warszawa 2002.

T. Walas, R. Nycz, Kulturowa teoria literatury. 2: Poetyki, problematyki, interpretacje, Kraków 2012.

A. Wierzbicka, Akty mowy, [w:] Semiotyka i struktura tekstu. Studia poświęcone VII Międzynarodowemu Kongresowi Slawistów, Warszawa 1973. Praca zbiorowa, red. M.R. Mayenowa, Wrocław 1973, s. 201-219.

A. Wierzbicka, Genry mowy, [w:] Tekst i zdanie. Zbiór studiów, red. T. Dobrzyńska, E. Janus, Wrocław 1983, s. 125-137. 
A. Wierzbicka, Różne kultury - różne języki - różne akty mowy, [w:] eadem, Język-umyst-kultura, wybór pod red. J. Bartmińskiego, Warszawa 1999, s. 193-227.

R. Wodak, Dyskurs populistyczny. Retoryka wykluczenia a gatunki języka pisanego, thum. J. Wawrzyniak, A. Wójcicki, [w:] Krytyczna analiza dyskursu. Interdyscyplinarne podejście do komunikacji społecznej, red. A. Duszak, N. Fairclough, Kraków 2008, s. 185-213.

Współczesne teorie społeczne. W kręgu ujęć paradygmatycznych, red. M.S. Szczepański, A. Śliz, Opole 2014.

K. Ziemba, Projekt komparatystyki wewnętrznej, [w:] Polonistyka w przebudowie. Literaturoznawstwo - wiedza o języku - wiedza o kulturze - edukacja. Zjazd Polonistów, Kraków, 22-25 września 2004, red. M. Czermińska et al., t. 1, Kraków 2005, s. 423-433. 